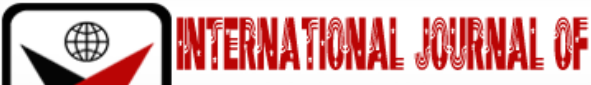

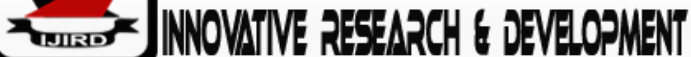

ISSN 2278-0211 (Online)

\section{The Studies of Ethno Medicinal Plants Use in Gastrointestinal Disorders}

\author{
Dr. DhrutiAnand Shukla \\ Assistant Professor, Department of Botany, Working on Traditional Herbal Medicines \\ Khyati Institute of Science, Gujarat University, Ahmedabad, Gujarat, India
}

\begin{abstract}
:
From ancient history Plants are considered as a main resource for food and basic medicine. Considering the world population and particularly in emerging nations like Asia and Africa, these communities are using plants as a primary source of medical aid. Medicinal plants are the foundation of resources (raw material) for both traditional systems and modern medicine.Their theory, understanding and practices are, different in many cases from the conventional medicines. Still the ancient use of many alternative medicine practices, including experience passed down from generation to generation and has proven the safety and efficacy of conventional medicine. The current research study is an attempt to gather the information and mode of application of ethno medicinal plants used in the treatment of gastrointestinal diseases and disorders. In various way the data were gathered from local people of Gandhinagar district more than 500 families were interviewed for the same. Collected data were reviewed with related research work. Selected ethno medicinal plants related information collected from different journals and books. Chemical constituents were taken from different Pharmaceutical journals for more collective and ethical study. The mode of applications of particular medicinal plants and its use for gastro problems are completely describe by the interviewing the different localities which they learnt from their ancestors. This research paper includes 5 Medicinal plants from various family with its Phytochemicals and Pharmacological application.
\end{abstract}

Keywords: Phytochemicals, Medicinal plants, gastrointestinal diseases, ethno medicine, traditional systems

\section{Introduction}

Plant resources have remained an integral part of human society throughout history. World Health Organization (WHO) estimated that about $80 \%$ of the developing world's population use traditional herbal medicines (Alves RR, Rosa IL, 2005). Ethno botany and Ethno pharmacology is the branch of knowledge dealing with herbal products used traditionally by years (Mahishi P, Srinivasa BH, Shivanna MB,2005). The use of medicinal plants treasure plays an important role in the lives of rural people, (Ahmad, 2003). More than half of the world's population depends upon traditional medicines to meet daily health requirements (Eddouks et al., 2002). It is a natural phenomenon that each community across the globe has a unique philosophy, belief, attitude, culture, and economic status. These are the basic factors, which are responsible for the variation in practicing traditional medicines (Čančarević A, Bugarski B, Šavikin K, Zdunić G, 2013). Current study is an important addition towards the preservation of folk ethno medicinal knowledge on plants and the efficacy of their derived products from an area not been previously explored. The erosion of traditional knowledge is mainly due to the slow and gradual introduction of allopathic medicines, current trend towards modernization, and exposure to technological era (Zavaleta ES, Hulvey KB. Realistic, 2004). Therefore, the issue of preserving ethno medicinal knowledge must be properly addressed; otherwise, the vertical and horizontal transfer rate of this knowledge within and across communities would be reduced and ultimately extinct in the near future. This concern has already been elevated in similar studies (Bussmann RW, Sharon D., 2006). The main aim of this study was to document the important plants which are using for their Specific role in treatment of gastrointestinal disorder. While doing the community study it is must to know the authentic data collection of traditional knowledge of plant, the mode of application, phytochemical study of specific selected plants or plant parts and its tendency of reliving the pain is very important. Collected traditional knowledge of plants will show in relation to medicinal use, reflecting a striking diversity of species and its uses, as well as their importance in popular plant therapy in the given discussion. These traditions could pave the way for future phytochemical and pharmacological studies and thereby give rise to new medicinal resources. This paper is referring to the traditional herbs used for the treatment of gastrointestinal diseases (abbrev. GI diseases or GI illnesses) refer to diseases involving the gastrointestinal tract, namely the esophagus, stomach, small intestine, large intestine and rectum, and the accessory organs of digestion, the liver, gallbladder, and pancreas. 


\section{Materials and Method}

For given research the regular field work was conducted for consecutive two years. During the field work data were collected on the bases of plant diversity, area of cultivation, ruler \& urban developed area and tribal community zones. Throughout the study the semi structured interview, group interviews, questionnaire, direct observation, interview with plant practitioners were arranged and the objectives were gathered. The timings for fieldwork were also selected according to the growth and collection season of the plants. Household respondents were also chosen through stratified sampling. Each study trip was well planned and executed effectively. Prior to any contact with the local people, the study and its objectives were introduced to the head of the area or localities. More than 100 families were interviewed and final data gathered related to gastrointestinal diseases. Collected database were segregated to identify the most common plant and its treatment. The mode of application was very place to place but the use of the particular medicine herb was same. After selecting best 5 Ethno medicinal plant, collected data were verified and reviewed through electronic search by using PubMed, SciFinder, Google Scholar, JCCC@INSTIRC and Web of Science. Some of the library literature on Ayurveda were also referred for the given research paper. Many of Pharmecognosy journals were also referred to identify the phytochemical properties of selected plants. Referred 5 plants are described in the tabulate form with its Botanical name, Family, its Phytochemicals, mode of applications and references.

\section{Observation}

During the study the number of data was gathered and out of that best 5 plants are selected here for the discussion. Table: 1 having information its Botanical information as well as about pharmacological activity of that particular plant while Table 2 is indicating the phytochemical list of those particular plants with referred information.

\begin{tabular}{|c|c|c|c|c|c|}
\hline Sr. No & Botanical Name & Family & $\begin{array}{l}\text { Part } \\
\text { Used }\end{array}$ & Pharmacological Activity & References \\
\hline 1 & Mangiferaindica L. & Anacardiaceae & $\begin{array}{l}\text { Mango } \\
\text { tree Bark } \\
\text { and } \\
\text { Unripe } \\
\text { Fruits }\end{array}$ & $\begin{array}{c}\text { Extract drunk in diarrhea, } \\
\text { preparing medicine for } \\
\text { Diarrhea and dysentery, } \\
\text { Antibacterial, anti- } \\
\text { inflammatory, antifungal, anti- } \\
\text { diabetic, antioxidant, antiviral } \\
\text { and ant parasitic properties }\end{array}$ & $\begin{array}{c}\text { (Maroyi A, 2011); } \\
\text { (Chitemerere TA, } \\
\text { Mukanganyama S, 2011); } \\
\text { (Wauthoz N, Balde A, } \\
\text { Balde ES, Van Damme M, } \\
\text { Duez P,2007) }\end{array}$ \\
\hline 2 & $\begin{array}{l}\text { Zingiberofficinale } \\
\text { Roscoe }\end{array}$ & Zingiberaceae & Rhizome & $\begin{array}{c}\text { Rhizome chewed and } \\
\text { swallowed as remedy for } \\
\text { stomach pains, Digestive } \\
\text { disorders, Antimicrobial, anti- } \\
\text { inflammatory, immune- } \\
\text { modulatory and anti-emetic } \\
\text { activities }\end{array}$ & $\begin{array}{c}\text { (Chigora P, Masocha R, } \\
\text { Mutenheri F, 2007); } \\
\text { (Paiva PMG, Gomes FS, } \\
\text { Napoleão TH, Sá RA, } \\
\text { Correia MTS, Coelho } \\
\text { LCBB, 2010); (Paraskeva } \\
\text { MP, Van Vuuren SF, Van } \\
\text { Zyl RL, Davids H, Viljoen } \\
\text { AM. 2008) }\end{array}$ \\
\hline 3 & Nicotianatobacum L. & Solanaceae & Leaves & $\begin{array}{l}\text { Powder of leaves applied on } \\
\text { wounds tabacum, Cytotoxic } \\
\text { activity and steroidal } \\
\text { glycosides, good remedies for } \\
\text { stomach ache, anti-microbial }\end{array}$ & $\begin{array}{c}\text { (Gelfand M, Drummond } \\
\text { RB, Mavi S, Ndemera B, } \\
\text { 1985); (Chen YK, Li XS, } \\
\text { Yang GY, Chen ZY, Hu QF, } \\
\text { Miao MM,2012); (Shvets } \\
\text { SA, Gutsu ON, Kintia PK, } \\
\text { 1996) }\end{array}$ \\
\hline 4 & Terminaliachebula & $\underline{\text { Combretaceae }}$ & Fruit & $\begin{array}{l}\text { Medicinal activities such as } \\
\text { analgesic, antioxidant, } \\
\text { hepatoprotective, antibacterial, } \\
\text { anticancer and immune- } \\
\text { modulatory activities. }\end{array}$ & $\begin{array}{l}\text { (Saraphanchotiwitthaya, } \\
\text { A., Sripalakit, P. and } \\
\text { Ingkaninan, K ,2008); } \\
\text { (Singh, A.S, 2011) }\end{array}$ \\
\hline 5 & Menthaspicata L. & $\underline{\text { Lamiaceae }}$ & Leaves & $\begin{array}{l}\text { Helps to treat gastroenteritis by } \\
\text { hydrating body, fighting } \\
\text { diarrhea, relieving pain, } \\
\text { reducing inflammation, help in } \\
\text { constipation and dysentery. } \\
\text { Antimicrobial and antioxidant } \\
\text { activities of three Mentha } \\
\text { species essential oils }\end{array}$ & $\begin{array}{l}\text { (Chiapponi E, Henriot C, } \\
\text { Bertrand X, Hocquet D, } \\
\text { Bornette G. Antibiotics } \\
\text { (Basel). 2020); ( } \\
\text { Ouakouak H, Benchikha N, } \\
\text { Hassani A, Ashour ML.J } \\
\text { Food Sci Technol. 2019) }\end{array}$ \\
\hline
\end{tabular}

Table 1: Medicinal Plants Used in Gastrointestinal Disorder with Scientific Name, Family, Part(S) Used and Use(S), Reported Ethno Medicinal /Pharmacological Activities, Related Reference Work 


\begin{tabular}{|c|c|c|c|}
\hline Sr. No & Botanical Name & Phytochemicals & References \\
\hline 1 & Mangiferaindica L. & $\begin{array}{l}\text { Phenolic acids, flavonoids, and pigments such } \\
\text { as chlorophyll and carotenoids. } \\
\text { macronutrients (carbohydrates, lipids and } \\
\text { fatty acids, proteins and amino acids, and } \\
\text { organic acids) and micronutrients (vitamins } \\
\text { and minerals) }\end{array}$ & $\begin{array}{l}\text { (Masibo, M., Qian, H, } \\
\text { 2008), } \\
\text { (Matheyambath, A. C., } \\
\text { Subramanian, J., Paliyath, } \\
\text { G., 2016) }\end{array}$ \\
\hline 2 & ZingiberofficinaleRoscoe & $\begin{array}{l}\text { Fatty oils proteins, carbohydrates, crude fiber, } \\
\text { ash, water, volatile oil, hydro-ethanol extracts, } \\
\beta \text {-zingiberene, antioxidant components } \\
\text { analysed were polyphenols, vitamin C, } \beta \\
\text { carotene, flavonoids and tannins. }\end{array}$ & $\begin{array}{c}\text { (Ekundayo O, Laakso I, } \\
\text { Hiltunen R. 1988), (Wang } \\
\text { J, Ke W, Bao R, Hu X, Chen } \\
\text { F. 2017) }\end{array}$ \\
\hline 3 & Nicotianatobacum L. & $\begin{array}{c}\text { Main polyphenols contained in the tobacco } \\
\text { leaf are rutin and chlorogenic acid. Amino } \\
\text { acids contained include glutamic acids, } \\
\text { asparagine, glutamine, and } \gamma \text {-Aminobutyric } \\
\text { acid }\end{array}$ & $\begin{array}{l}\text { (Shmuk, A.A., 1953); } \\
\text { (Fujimori, T.; Kasuga, R.; } \\
\text { Matsushita, H.; Kaneko, } \\
\text { H.; Noguchi, M. 1976) }\end{array}$ \\
\hline 4 & Terminaliachebula & $\begin{array}{c}\text { Different types of phytochemicals such } \\
\text { as alkaloids, flavonoids, saponin, phenolic } \\
\text { compounds, steroids, carboxylic acid, tannin } \\
\text { and glycoside. }\end{array}$ & $\begin{array}{c}\text { (Sharma P, Prakash T, } \\
\text { Kotresha D, Ansari MA, } \\
\text { Sahrm UR, Kumar B, } \\
\text { Debnath J, Goli D 2010); } \\
\text { (Nigam M, Mishra AP, } \\
\text { Adhikari-Devkota A, Dirar } \\
\text { AI, Hassan MM, Adhikari } \\
\text { A, Belwal T, Devkota HP. } \\
\text { 2020) }\end{array}$ \\
\hline 5 & $\frac{\text { Menthaspicata }}{\text { L. }}$ & 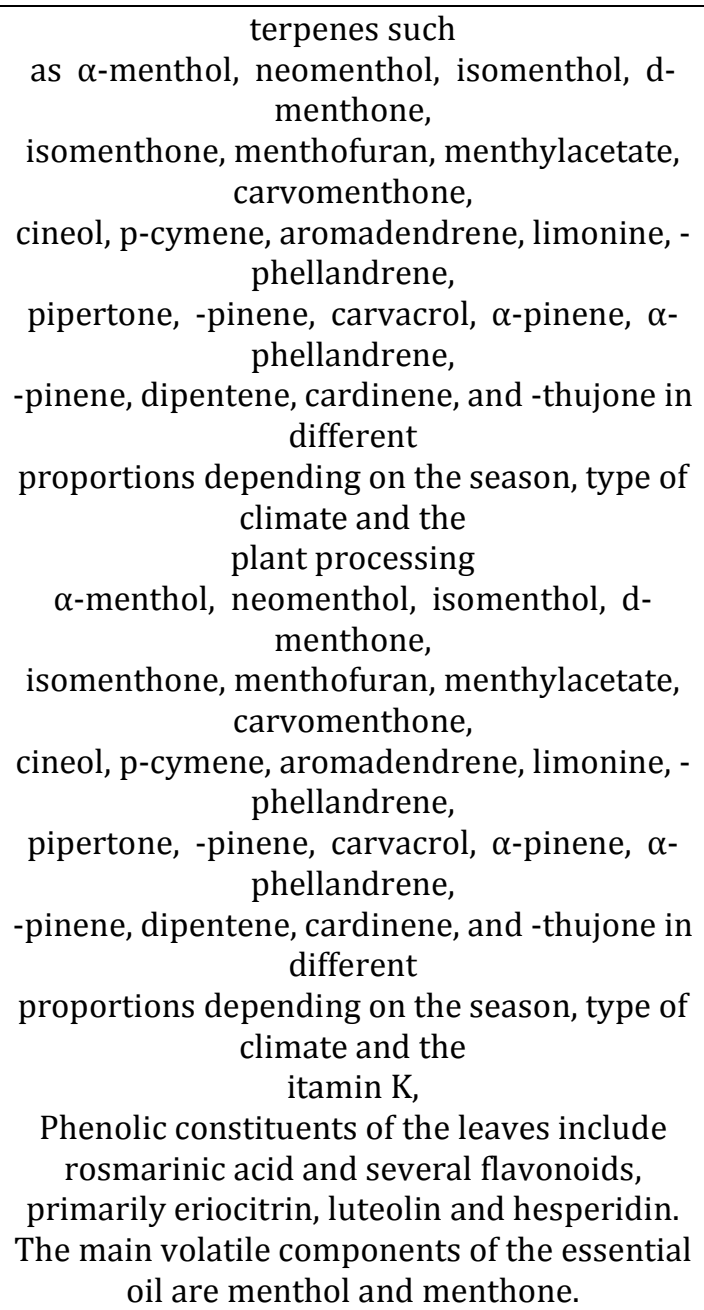 & $\begin{array}{l}\text { (Spirling LI, Daniels IR } \\
\text { 2001); ( } \\
\text { Mckay DL, Blumberg JBA. } \\
\text { 2006); } \\
\text { ( Strzelecka H, Kowalski J. } \\
\text { 2000) }\end{array}$ \\
\hline
\end{tabular}

Table 2: Indicating the Phytochemical List of That Particular Plant with Referred Information

People are using different mode of applications or the combination of herb with cold/ warm water, using of plant abstract, chewing the raw fruits or leaves or important part of herb, in some of the application mixture or formulation of 
the herbs used as per their connivance, preparing herb reminds by soaking the herbs in water overnight, making of tonic with sugar syrup etc.

\section{Conclusion}

Herbal medicinal Plants are either used as indigenous therapy or as isolated active principles for a common source of medicine. Indigenous ethno pharmacology has been considered as an important tool in the exploration of new medicines for community but yet authentic data is much needed for the same. Herbal medicines are a common method of complementary and alternative medicine used on the treatment of various forms of ailments around the globe. Traditionally all medicinal preparations were derived from plants, whether in the simple form of plant parts or the more sophisticated way of crude extracts, mixtures, etc. this herbal formulation claimed to have major medicinal benefits in many of Gastrointestinal disease where phytochemical evidences and study is must needed. Given research documentation can be help full to the field of Pharmecognocy and can helpful for future generation.

\section{References}

i. Ouakouak H, Benchikha N, Hassani A, Ashour ML.J Food Sci Technol. 2019 Dec;56(12):5346-5353. doi: 10.1007/s13197-019-04005-z. Epub 2019 Aug 8. PMID: 31749482

ii. Chiapponi E, Henriot C, Bertrand X, Hocquet D, Bornette G. Antibiotics (Basel). 2020 Jun 18;9(6):335. doi: 10.3390/antibiotics9060335.PMID: 32570743

iii. Saraphanchotiwitthaya, A., Sripalakit, P. and Ingkaninan, K. (2008). Effects of TerminaliabelericaRoxb. Methanolic extract on mouse immune response in vitro. MaejoInt J Sci Tech. 2:400-407.

iv. Singh, A.S. (2011). Herbalism phytochemistry and Ethanopharmacology, Science publishers. 357-361

v. Gelfand M, Drummond RB, Mavi S, Ndemera B: The traditional medical practitioner in Zimbabwe: his principles of practice and pharmacopoeia. Gweru: Mambo Press; 1985.

vi. Chen YK, Li XS, Yang GY, Chen ZY, Hu QF, Miao MM: Phenolic compounds from Nicotianatabacum and their biological activities. J Asian Nat Prod Res 2012, 14:450-456. 130.

vii. Shvets SA, Gutsu ON, Kintia PK: Steroidal glycosides from Nicotianatabacum L. seeds and their biological activity. AdvExp Med Biol 1996, 405:247-257

viii. Maroyi A: Ethnobotanical study of medicinal plants used by people in Nhema communal area, Zimbabwe. J Ethnopharmacol 2011, 136:347-354

ix. Chitemerere TA, Mukanganyama S: In vitro antibacterial activity of selected medicinal plants from Zimbabwe. African J Pl Sci Biotech 2011, 5:1-7.

X. Wauthoz N, Balde A, Balde ES, Van Damme M, Duez P: Ethnopharmacology of Mangiferaindica L. bark and pharmacological studies of its cain C-Glucosylxanthone, Mangiferin. Int J Biomed PharmaceutSci 2007, 1:112119.

xi. Chigora P, Masocha R, Mutenheri F: The role of indigenous medicinal knowledge (IMK) in the treatment of ailments in rural Zimbabwe: the case of Mutirikwi communal lands. J Sustainable Develop Africa 2007, 9:2643.

xii. Paiva PMG, Gomes FS, NapoleãoTH, Sá RA, Correia MTS, Coelho LCBB: Antimicrobial activity of secondary metabolites and lectins from plants. In Current Research, Technology and Education Topics in Applied Microbiology and Microbial Biotechnology. Edited by Mendez-Vilas A. Brazil: Formatex; 2010:396-406.

xiii. Paraskeva MP, Van Vuuren SF, Van Zyl RL, Davids H, Viljoen AM: The in vitro biological activity of selected South African Commiphora species. J Ethnopharmacol 2008, 119:673-679.

xiv. Ahmad, M., 2003. Ethnobotanical and taxonomic studies of economically important plants of Tehsil Attock. M. Phil Thesis, Quaid-e-Azam University, Islamabad, Pakistan.

xv. Eddouks, M., M. Maghrani, A. Lemhadri, M.L. Ouahidi and H. Jouad, 2002. Ethnopharmacological survey of medicinal plants used for the treatment of diabetes mellitus hypertension and cardiac diseases in the Southeast region of Morocco (Tafilalet). J. Ethnopharmacol., 82: 93-103. Direct Link |

xvi. Alves RR, Rosa IL. Why study the use of animal products in traditional medicines? J EthnobiolEthnomed. 2005;1(1):5. PubMed PubMed Central Article Google Scholar

xvii. Čančarević A, Bugarski B, Šavikin K, Zdunić G. Biological activity and ethnomedicinal use of Thymus vulgaris and Thymus serpyllum. Lekovitesirovine. 2013;33:3-17. Google Scholar

xviii. Bussmann RW, Sharon D. Traditional medicinal plant use in Northern Peru: tracking two thousand years of healing culture. J EthnobiolEthnomed. 2006;2(1):47. PubMed PubMed Central Article Google Scholar

xix. Zavaleta ES, Hulvey KB. Realistic species losses disproportionately reduce grassland resistance to biological invaders. Sci. 2004;306:1175-7. CAS Article Google Scholar

xx. Mahishi P, Srinivasa BH, Shivanna MB. Medicinal plant wealth of local communities in some villages in Shimoga District of Karnataka India. J Ethnopharmacol. 005;98(3):307-12. PubMed Article Google Scholar

xxi. Masibo, M., Qian, H. (2008). Major mango polyphenols and their potential significance to human health. Compr. Rev. Food Sci. Food Saf. 7, 309-319. doi: 10.1111/j.1541-4337.2008.00047.x CrossRef Full Text | Google Scholar

xxii. Matheyambath, A. C., Subramanian, J., Paliyath, G., (2016). "Mangoes reference module in food science," in Encyclopedia of food and health. Eds. Paul, B. C., Told, F. F. (Switzerland: Elsevier), 641-645. doi: 10.1016/B978-0-12-384947-2.00442-6 CrossRef Full Text | Google Scholar 
xxiii. Ekundayo 0, Laakso I, Hiltunen R. Composition of ginger (Zingiberofficinale roscoe) volatile oils from Nigeria. Flavour Fragrance J. 1988;3(2):85-90. https://doi.org/10.1002/ffj.2730030207.

xxiv. Return to ref 10 in articleCAS Article Google Scholar

xxv. Wang J, Ke W, Bao R, Hu X, Chen F. Beneficial effects of ginger Zingiberofficinale Roscoe on obesity and metabolic syndrome: a review. Ann N Y Acad Sci. 2017;1398(1):83-98. https://doi.org/10.1111/nyas.13375. Article PubMed Google Scholar

xxvi. Shmuk, A.A., 1953. The Chemistry and Technology of Tobacco. Vol. III, Pischetomizedate Publishers, Moscow.

xxvii. Fujimori, T.; Kasuga, R.; Matsushita, H.; Kaneko, H.; Noguchi, M. Neutral aroma constituents in Burley tobacco. Agric. Biol. Chem. 1976, 40, 303-315. [Google Scholar] [CrossRef]

xxviii. Nigam M, Mishra AP, Adhikari-Devkota A, Dirar AI, Hassan MM, Adhikari A, Belwal T, Devkota HP.Phytother Res. 2020 Oct;34(10):2518-2533. doi: 10.1002/ptr.6702. Epub 2020 Apr 20.PMID: 32307775

xxix. Sharma P, Prakash T, Kotresha D, Ansari MA, Sahrm UR, Kumar B, Debnath J, GoliD.Pharm Biol. 2011 Mar;49(3):262-8. doi: 10.3109/13880209.2010.503709.PMID: 21323478

xxx. Spirling LI, Daniels IR.J R SocPromot Health. 2001 Mar;121(1):62-3. doi: 10.1177/146642400112100113.PMID: 11329700

xxxi. Mckay DL, Blumberg JBA. Review of the bioactivity and potential health benefits of peppermint tea (Menthapiperita L.). Phytother Res. 2006; 20: 619-633. [PubMed] [Google Scholar]

xxxii. 15. Strzelecka H, Kowalski J. Encyclopedia of herbalism and herbal medicine. Warszawa: WydawnictwoNaukowe PWN; 2000. [Google Scholar] 